\title{
Congestive Heart Failure is a Systemic Illness: A Role for Minerals and Micronutrients
}

\author{
Shadwan Alsafwah, MD; Stephen P. LaGuardia, MD; Maximiliano Arroyo, MD; Brian K. Dockery, MD; \\ Syamal K. Bhattacharya, PhD; Robert A. Ahokas, PhD; and Kevin P. Newman, MD
}

\begin{abstract}
Congestive heart failure (CHF) is a clinical syndrome that features a failing heart together with signs and symptoms arising from renal retention of salt and water, mediated by attendant neurohormonal activation, and which prominently includes the renin-angiotensin-aldosterone system. More than this cardiorenal perspective, $\mathrm{CHF}$ is accompanied by a systemic illness whose features include an altered redox state in diverse tissues and blood, an immunostimulatory state with proinflammatory cytokines and activated lymphocytes and monocytes, and a wasting of tissues that includes muscle and bone. Based on experimental studies of aldosteronism and clinical findings in patients with CHF, there is an emerging body of evidence that secondary hyperparathyroidism is a covariant of CHF. The aldosteronism of CHF predisposes patients to secondary hyperparathyroidism because of a chronic increase in $\mathrm{Ca}^{2+}$ and $\mathrm{Mg}^{2+}$ losses in urine and feces, with a fall in their serum ionized levels and consequent secretion of parathyroid hormone. Secondary hyperparathyroidism accounts for bone resorption and contributes to a fall in bone strength that can lead to nontraumatic fractures. The long-term use of a loop diuretic with its attendant urinary wasting of $\mathrm{Ca}^{2+}$ and $\mathrm{Mg}^{2+}$ further predisposes patients to secondary hyperparathyroidism and attendant bone loss. Aberrations in minerals and micronutrient homeostasis that includes $\mathrm{Ca}^{2+}, \mathrm{Mg}^{2+}$, vitamin $\mathrm{D}$, zinc and selenium appear to be an integral component of pathophysiologic expressions of CHF that contributes to its systemic and progressive nature. This broader perspective of CHF, which focuses on the importance of secondary hyperparathyroidism and minerals and micronutrients, raises the prospect that dietary supplements could prove remedial in combination with the current standard of care.
\end{abstract}

Keywords: Aldosteronism; Congestive heart failure; Hyposelenemia; Hypovitaminosis D; Hypozincemia; Secondary hyperparathyroidism

$\mathrm{H}$ eart failure is a worldwide health problem of ever increasing proportions, particularly among the elderly. Both systolic and diastolic left ventricular dysfunction can eventuate in a clinical syndrome having characteristic signs and symptoms, known as congestive heart failure (CHF), which arise from congested organs and hypoperfused tissues. The origins of CHF are rooted in a salt-avid state mediated by neurohormonal activation that includes the reninangiotensin-aldosterone and adrenergic nervous systems.

Beyond this cardiorenal perspective, it is now recognized that CHF syndrome involves more than a failing heart and saltretaining kidneys. CHF is accompanied by a systemic illness that contributes to its progressive nature. It too appears as a result of neurohormonal activation and features oxidative

Reprint Requests: Kevin P. Newman, MD, Division of Cardiovascular Diseases, University of Tennessee Health Science Center, 920 Madison Avenue, Suite 300, Memphis, TN 38I63, Tel: $901-448-53$ I4, Fax: $901-448-8084$, Email: KNewman@utmem.edu stress in diverse tissues, immune cell activation and a loss of soft tissues and bone that eventuates in a wasting syndrome termed cardiac cachexia. A dyshomeostasis of minerals $\left(\mathrm{Ca}^{2+}\right.$ and $\left.\mathrm{Mg}^{2+}\right)$ contribute to the appearance of secondary hyperparathyroidism, while insufficient micronutrients (vitamin D, zinc and selenium) predispose patients to secondary hyperparathyroidism and to reduced antioxidant defenses. Herein, we consider this broader perspective of $\mathrm{CHF}$, its systemic nature and the role of minerals and micronutrients.

\section{CHF: A Salt-Avid State}

$\mathrm{CHF}$ is a clinical syndrome consisting of signs and symptoms that arise from congested organs and hypoperfused tissues. Its origins are rooted in $\mathrm{Na}^{+}$and water

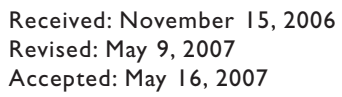

doi : $10.3121 / \mathrm{cmr} .2007 .737$ 
retention, and is characterized by a urinary sodium/potassium $(\mathrm{Na} / \mathrm{K})$ ratio of $<1.0$. CHF has its origin rooted in an activation of several circulating neurohormonal systems, including the renin-angiotensin-aldosterone system and the sympathetic nervous system, which are based on impaired renal perfusion with associated overproduction of angiotensin II, aldosterone and catecholamines. These neurohormones overwhelm the biologic actions of atrial and brain natriuretic peptides that had maintained urinary $\mathrm{Na}$ excretion (urinary $\mathrm{Na} / \mathrm{K}>1.0$ ), euvolemia and a state of clinical compensation. Elevations in plasma renin activity, angiotensin II and aldosterone are integral features of the "volume-overloaded" state expressed as expanded intra- and extravascular volumes and the resultant clinical decompensation represented by CHF. 1,2 The importance of these hormones is underscored by the proven efficacy of pharmacologic interventions that interfere with these hormones. 3,4

\section{CHF: A Systemic IIIness}

A broader perspective of CHF recognizes its systemic nature which has been described as a neuroendocrine-immune system interface gone awry. ${ }^{5}$ This illness includes (1) the presence of oxidative stress with reactive oxygen and nitrogen intermediates that overwhelm endogenous antioxidant defenses in such diverse tissues as skin, skeletal muscle, heart, peripheral blood mononuclear cells (lymphocytes and monocytes) and blood, (2) a proinflammatory phenotype with activated peripheral blood mononuclear cells and elevations in circulating chemokines and cytokines, such as interleukin6 and tumor necrosis factor (TNF)- $\alpha$, and (3) a catabolic state with loss of soft tissues and bone due, in part, to negative caloric and nitrogen balance that eventuates in a wasting syndrome termed cardiac cachexia. Factors contributing to

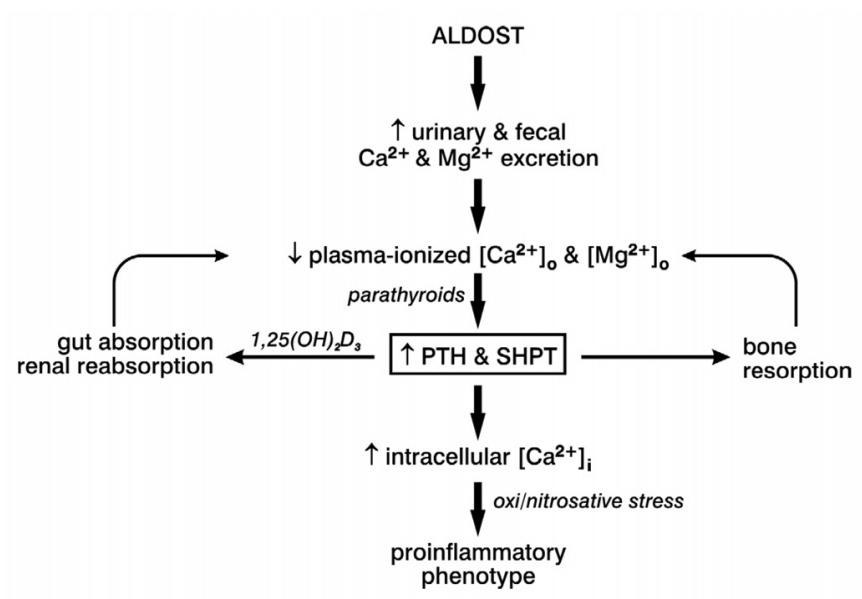

Figure 1. Aldosteronism is associated with increased urinary and fecal losses of $\mathrm{Ca}^{2+}$ and $\mathrm{Mg}^{2+}$ that leads to a fall in their plasma ionized concentration and increased secretion of parathyroid hormone (PTH). Secondary hyperparathyroidism (SHPT), in turn, seeks to restore extracellular $\mathrm{Ca}^{2+}$ and $\mathrm{Mg}^{2+}$ homeostasis through bone resorption and increased absorption of these cations by gut and kidneys. Despite these losses and fall in extracellular $\mathrm{Ca}^{2+}$ and $\mathrm{Mg}^{2+}$, PTH promotes a paradoxical overload of intracellular $\mathrm{Ca}^{2+}$ in diverse tissues. $\mathrm{Ca}^{2+}$ overloading leads to the induction of oxidative stress. the appearance of this systemic illness include secondary hyperparathyroidism, based on urinary and fecal wasting of $\mathrm{Ca}^{2+}$ and $\mathrm{Mg}^{2+}$, and reduced plasma ionized $\left[\mathrm{Ca}^{2+}\right]_{\mathrm{o}}$ and $\left[\mathrm{Mg}^{2+}\right]_{0}$ which raise plasma parathyroid hormone (PTH) levels. ${ }^{6}$ PTH-mediated $\mathrm{Ca}^{2+}$ overloading of diverse cells, in turn, leads to the induction of oxidative stress. ${ }^{7}$ Micronutrient deficiencies also contribute to the induction of oxidative stress by reducing the activity of antioxidant defenses provided by $\mathrm{Cu} / \mathrm{Zn}$-superoxide dismutase and Se-glutathione peroxidase. ${ }^{8}$

\section{Insights from an Animal Model}

Experimental studies in rats have focused on one aspect of the renin-angiotensin-aldosterone system activation, namely chronic aldosteronism, where plasma renin activity and angiotensin II are each suppressed, while plasma aldosterone levels are raised to those found in human CHF which are inappropriate for dietary $\mathrm{Na}^{+}$intake consisting of $1 \%$ sodium chloride $(\mathrm{NaCl})$ in drinking water. A $0.4 \%$ potassium chloride $(\mathrm{KCl})$ supplement is provided to these rats to prevent hypokalemia. Spironolactone, an aldosterone receptor antagonist, can be used as a co-treatment.

Using this rat model of aldosteronism, several aspects of the systemic nature of CHF were elucidated (figure 1). First, aldosterone/salt treatment is accompanied by a marked increase in urinary and fecal excretion of $\mathrm{Ca}^{2+}$ and $\mathrm{Mg}^{2+} .6,9$ These losses are found at week 1 of the aldosterone/salt treatment and are sustained over the course of 6 weeks of continuous treatment. For a fixed dietary intake of these divalent cations, their continued loss from both kidneys and colon leads to a fall in plasma ionized $\left[\mathrm{Ca}^{2+}\right]_{\mathrm{o}}$ and $\left[\mathrm{Mg}^{2+}\right]_{\mathrm{o}}$, each of which are stimuli to the parathyroid glands' release of PTH. Plasma PTH levels are increased throughout the aldosterone/salt treatment in an attempt to restore extracellular levels of these cations. This secondary hyperparathyroidism leads to bone resorption and increased renal and gastrointestinal absorption of $\mathrm{Ca}^{2+}$ and $\mathrm{Mg}^{2+}$ promoted by $1,25(\mathrm{OH})_{2} \mathrm{D}_{3} .6,9,10$ Bone mineral density declines during the course of aldosterone/salt treatment and is accompanied by a reduction in bone strength to resist flexor stress. ${ }^{6}$

Elevations in plasma PTH are accompanied by an excessive accumulation of intracellular $\mathrm{Ca}^{2+}$ in such diverse tissues as heart, skeletal muscle and peripheral blood mononuclear cells. This has been referred to as a $\mathrm{Ca}^{2+}$ paradox. ${ }^{11}$ As is the case with ischemia/reperfusion injury or excess circulating catecholamines, intracellular $\mathrm{Ca}^{2+}$ overloading is accompanied by the appearance of oxidative stress. This is expressed as (1) an activation of nicotinamide adenosine dinucleotide phosphate oxidase, a source of superoxide in vascular tissues; (2) an activation of a redox-sensitive transcription factor $(\mathrm{NF})-\kappa \mathrm{B}$, together with upregulated expression of the proinflammatory genes it governs; (3) reactive oxygen (e.g., superoxide, $\mathrm{H}_{2} \mathrm{O}_{2}$ ) and nitrogen (e.g., peroxynitrite) species in diverse tissues; and (4) a fall in 
plasma $\alpha_{1}$-antiproteinase activity, an inverse correlate of oxidative stress. ${ }^{12-17}$

The contribution of PTH-mediated $\mathrm{Ca}^{2+}$ overloading during aldosterone/salt treatment and induction of oxidative stress has been demonstrated by co-treating rats with either spironolactone, which prevents increased urinary and fecal $\mathrm{Ca}^{2+}$ and $\mathrm{Mg}^{2+}$ excretion, and thereby, secondary hyperparathyroidism, ${ }^{6}$ parathyroidectomy, ${ }^{7}$ or a $\mathrm{Ca}^{2+}$ channel blocker. ${ }^{13}$

\section{Minerals and Micronutrients in CHF}

Studies in rats with aldosteronism drew attention to the potential importance of $\mathrm{Ca}^{2+}$ and $\mathrm{Mg}^{2+}$ wasting in patients with CHF. This not only included urinary and fecal losses of these cations associated with aldosteronism, an integral feature of the salt-avid state found in $\mathrm{CHF}, 1,2,18-21$ but also the chronic use of furosemide, a loop diuretic, which further raises urinary $\mathrm{Ca}^{2+}$ and $\mathrm{Mg}^{2+}$ excretion. ${ }^{22}$ Secondary hyperparathyroidism with hypercalciuria has been observed in patients with advanced CHF awaiting cardiac transplantation and who had received chronic furosemide treatment. ${ }^{23,24}$ These persons were also found to have a reduction in bone mineral density in keeping with osteopenia or, in more advanced cases, with osteoporosis. Among nursing home residents, daily furosemide dosage is an important predictor of secondary hyperparathyroidism. ${ }^{25}$ Chronic furosemide treatment, even in the usual dosage of 40 or $80 \mathrm{mg}$, is also associated with heightened urinary losses of thiamine 26 and ultimately leading to a deficiency of vitamin $\mathrm{B}_{1}$.

In patients with $\mathrm{CHF}$, having reduced effort tolerance because of their limiting symptoms, a housebound lifestyle follows and predisposes them to the appearance of hypovitaminosis D. Reductions in serum $25(\mathrm{OH}) \mathrm{D}$ have been reported in some Caucasian patients who were hospitalized in New York City with CHF awaiting transplantation. ${ }^{24}$ Hypovitaminosis D has also been found in some non-hospitalized European patients with CHF. ${ }^{27}$ In African-Americans, hypovitaminosis D is prevalent. Melanin is a natural sunscreen that requires longer exposure to sunlight for the skin to generate vitamin D. ${ }^{28}$ It also absorbs heat and therefore may contribute to an avoidance of sunlight in warm summer months. Recent findings observed during June to August in 2005 in Memphis, TN (latitude $35^{\circ} \mathrm{N}$ ) indicate this is the case in AfricanAmerican outpatients with compensated heart failure and reduced ejection fraction $(<35 \%)$, and those admitted with decompensated heart failure and comparable systolic dysfunction. ${ }^{29,30}$

Compromised 25(OH)D stores threaten $\mathrm{Ca}^{2+}$ homeostasis. This may relate not only to reduced sunlight exposure but also to a failure of senescent skin to adequately generate vitamin $\mathrm{D}$; obesity, where adipocytes sequester it; and to reduced dietary $\mathrm{Ca}^{2+}$ intake with an avoidance of dairy products secondary to lactose intolerance. ${ }^{28}$ Thus, African-Americans with hypovitaminosis D who develop CHF with secondary

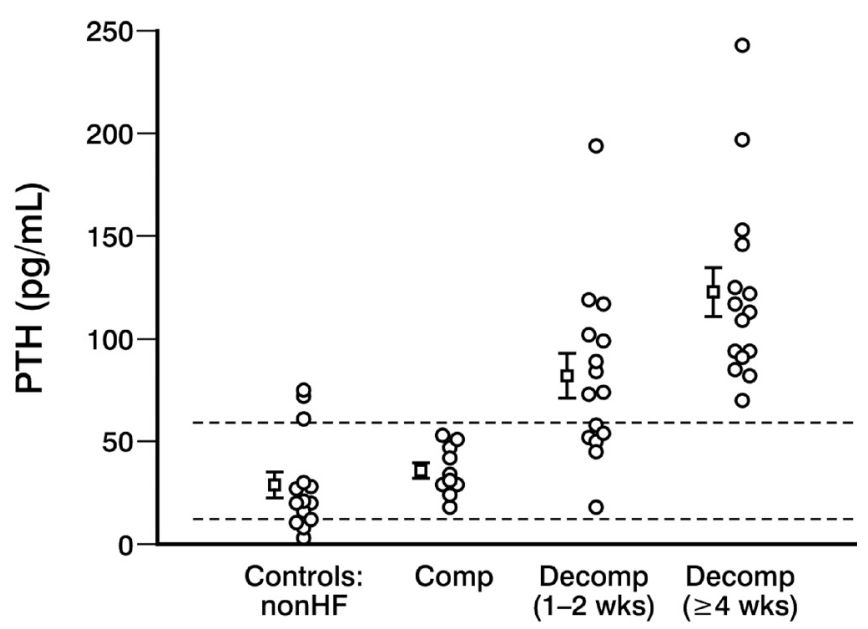

Figure 2. Serum PTH levels are increased above the upper limits of normal $(65 \mathrm{pg} / \mathrm{ml}$, dotted line) in all African-American patients with protracted ( $\geq 4$ weeks) and in many with shorter duration (1-2 weeks) decompensated (decomp) heart failure. This is not the case in those with compensated (comp) failure or in those without heart failure (controls: nonHF). Adapted with permission from Arroyo et al. Micronutrients in AfricanAmericans with decompensated and compensated heart failure. Transl Res 2006;148:301-308. ${ }^{30}$ Copyright 2006 Elsevier. All rights reserved.

aldosteronism and who then are treated with furosemide, may be particularly predisposed to secondary hyperparathyroidism. Elevations in serum PTH, together with reduced serum ionized $\left[\mathrm{Ca}^{2+}\right]_{\mathrm{o}}$ and $\left[\mathrm{Mg}^{2+}\right]_{\mathrm{o}}$, have been found in African-Americans hospitalized in Memphis with decompensated failure of $\geq 4$ weeks despite medical treatment, which is in keeping with prolonged activation of the renin-angiotensin-aldosterone system, and in many, but not all African-Americans with treated CHF of shorter duration (1-2 weeks) or in non-heart failure controls (figure 2). PTH levels were not increased in AfricanAmericans with compensated, treated failure or in non-heart failure patients serving as controls. ${ }^{29,30}$

Calculated creatinine clearance ranged between $60 \mathrm{ml} / \mathrm{min}$ to $90 \mathrm{ml} / \mathrm{min}$ in these African-American patients with either decompensated or compensated heart failure and therefore, marked renal failure (creatinine clearance $<30 \mathrm{ml} / \mathrm{min}$ ) which is accompanied by secondary hyperparathyroidism, does not account for the appearance of secondary hyperparathyroidism. Instead, a compromised $\mathrm{Ca}^{2+}$ balance appears responsible. None of the enrolled African-American patients had disorders that would reduce $\left[\mathrm{Ca}^{2+}\right]_{\mathrm{o}}$ or $\left[\mathrm{Mg}^{2+}\right]_{\mathrm{o}}$, such as sepsis, pancreatitis, blood transfusion, surgery, chronic alcoholism or metabolic alkalosis. Moreover, none had a disorder known to adversely affect bone metabolism, including rheumatoid arthritis, Paget's disease, osteomalacia, primary hyperparathyroidism or gastric resection or inflammatory bowel disease. 
The importance of our findings is further supported by recently published interventional studies with nutrients. ${ }^{31-33}$ Schleithoff et al $^{31}$ reported on a 9-month clinical trial conducted in men with CHF (mean age 55 years) who were randomly assigned to receive either placebo or vitamin D (50 $\mu \mathrm{g} / \mathrm{d} ; 2000 \mathrm{IU} / \mathrm{d})$. Although the authors found no effect of vitamin $\mathrm{D}$ on either left ventricular function or 15-month survival rates, the serum concentrations of TNF- $\alpha$ decreased with vitamin $\mathrm{D}$ treatment. In contrast, concentrations of interleukin-10, an anti-inflammatory cytokine, increased. The trial confirmed that vitamin D supplementation affects immune-modulating cytokines in desirable ways and suggested that vitamin D has cardioprotective effects.

Furthermore, the study by Schleithoff et al shed some light on another aspect, the fact that higher doses of vitamin D have greater effects on regulatory molecules of the immune system. ${ }^{31}$ This would be clear by contrasting this study with that conducted by Witte and Clark ${ }^{32}$ who used vitamin D at $10 \mu \mathrm{g} / \mathrm{d}$ (400 IU/d), which did not affect cytokine concentrations. Another study by Mahon et al ${ }^{33}$ produced only modest responses with $25 \mu \mathrm{g}$ vitamin D/d (1000 IU/d).

In addition to compromised stores of vitamins $\mathrm{D}$ and $\mathrm{B}_{1}$ in patients with $\mathrm{CHF}$, other micronutrients need to be considered. These include $\mathrm{Zn}$ and $\mathrm{Se}$, each of which is integral to the activity of endogenous antioxidant defenses. Obtained primarily from dietary sources, reductions in serum $\mathrm{Zn}$ and Se have been associated with the appearance of a dilated cardiomyopathy. ${ }^{34-37}$ Of interest, urinary Zn excretion is increased in response to treatment with angiotensinconverting enzyme inhibitor or angiotensin receptor antagonist and where hypozincemia is held responsible for the appearance of disturbances of taste. ${ }^{38-41}$ In recent studies conducted in Memphis in middle-aged African-American patients having a dilated cardiomyopathy of uncertain etiology, reductions in serum $\mathrm{Zn}$ and Se were found and included those patients hospitalized with decompensated failure and outpatients with compensated failure. Specifically, serum $\mathrm{Zn}$ was below normal range (75-140 $\mu \mathrm{g} / \mathrm{dl})$ in 11 of 15 patients with protracted CHF $(67 \pm 5$; $47-107 \mu \mathrm{g} / \mathrm{dl}), 8$ of 10 patients with 1 -week to 2 -weeks CHF $(65 \pm 4 ; 43-79 \mu \mathrm{g} / \mathrm{dl})$ and 5 of 6 patients with compensated failure $(70 \pm 2 ; 63-79 \mu \mathrm{g} / \mathrm{dl})$. Serum $\mathrm{Se}$ (normal range 85-125 $\mu \mathrm{g} / \mathrm{l})$ was reduced in all 15 patients with $\geq 4$ weeks CHF (56 \pm 3 ; 36-72 $\mu \mathrm{g} / 1), 9$ of 10 with short-term CHF $(63 \pm 4 ; 45-86$ $\mu \mathrm{g} / \mathrm{l})$ and 5 of 6 compensated patients $(71 \pm 7 ; 56-100 \mu \mathrm{g} / \mathrm{l}) .{ }^{30}$ The etiologic basis and functional significance of these findings remains to be determined.

The importance of the multinutrient deficiency in CHF can be further verified by another interventional study by Witte et $\mathrm{al}^{42}$ where $30 \mathrm{CHF}$ patients were randomized to receive capsules containing a combination of high-dose minerals and vitamins (calcium, magnesium, zinc, copper, selenium, vitamin $\mathrm{A}$, thiamine, riboflavin, vitamin $\mathrm{B}_{6}$, folate, vitamin $\mathrm{B}_{12}$, vitamin $\mathrm{C}$, vitamin $\mathrm{E}$, vitamin $\mathrm{D}$ and coenzyme $\mathrm{Q} 10$ ) or placebo for 9 months in a double-blind fashion. All subjects were on stable optimal medical therapy for at least 3 months before enrollment. At the end of the follow-up period, left ventricular volumes were reduced in the intervention group with no change in the placebo group $(-13.1 \%$ [17.1] vs. $+3.8 \%$ [10.0]; $P<0.05)$. The left ventricular ejection fraction increased by $5.3 \% \pm 1.4 \%$ in the intervention group and was unchanged in the placebo group $(P<0.05)$. Furthermore, the intervention group had a significant improvement in quality of life score between enrollment and study end, whereas those taking placebo had a slight deterioration.

\section{Summary and Conclusions}

Over the past 50 years, the clinical syndrome CHF has undergone a transformation as to our understanding of its pathophysiologic expressions: from (a) a cardiocentric perspective, where myocardial contractility was the sole focus to (b) an appreciation of neurohormonal activation (the cardiorenal perspective with its salt-avidity) to (c) the current paradigm that includes each of the above together with an associated systemic component. The systemic illness of CHF features oxidative stress, a proinflammatory phenotype and a wasting of tissues. Disturbances in minerals and micronutrients are an integral feature of this illness and likely contribute to its progressive nature. These disturbances relate to chronic neurohormonal activation, as well as to environmental factors (e.g., reduced sunlight exposure and dietary $\mathrm{Ca}^{2+}$ intake) and today's standard of care with a loop diuretic and angiotensin-converting enzyme inhibitor.

In recognizing the importance of a dyshomeostasis in $\mathrm{Ca}^{2+}$, $\mathrm{Mg}^{2+}$, vitamins $\mathrm{D}$ and $\mathrm{B}_{1}, \mathrm{Zn}$ and $\mathrm{Se}$ in $\mathrm{CHF}$, its prevention and management will call into question the need for addressing these and other minerals and micronutrients in everyday practice. Based on data presented here, we feel strongly that patients with $\mathrm{CHF}$ need daily nutrient supplement in addition to their habitual diet. The time is at hand to focus attention on the nutritional aspects of CHF that will complement today's standard of care.

\section{References}

1. Swedberg K, Eneroth P, Kjekshus J, Wilhelmsen L. Hormones regulating cardiovascular function in patients with severe congestive heart failure and their relation to mortality. CONSENSUS Trial Study Group. Circulation 1990; 82:1730-1736.

2. Francis GS, Benedict C, Johnstone DE, Kirlin PC, Nicklas J, Liang CS, Kubo SH, Rudin-Toretsky E, Yusuf S. Comparison of neuroendocrine activation in patients with left ventricular dysfunction with and without congestive heart failure. A substudy of the Studies of Left Ventricular Dysfunction (SOLVD). Circulation 1990;82:1724-1729.

3. The SOLVD Investigators. Effect of enalapril on survival in patients with reduced left ventricular ejection fractions and congestive heart failure. N Engl J Med 1991;325:293-302.

4. Pitt B, Zannad F, Remme WJ, Cody R, Castaigne A, Perez A, Palensky J, Wittes J. The effect of spironolactone on morbidity and mortality in patients with severe heart failure. Randomized Aldactone Evaluation Study Investigators. N Engl J Med 1999;341:709-717. 
5. Weber KT. The neuroendocrine-immune interface gone awry in aldosteronism. Cardiovasc Res 2004;64:381-383.

6. Chhokar VS, Sun Y, Bhattacharya SK, Ahokas RA, Myers LK, Xing Z, Smith RA, Gerling IC, Weber KT.

Hyperparathyroidism and the calcium paradox of aldosteronism. Circulation 2005;111:871-878.

7. Vidal A, Sun Y, Bhattacharya SK, Ahokas RA, Gerling IC, Weber KT. Calcium paradox of aldosteronism and the role of the parathyroid glands. Am J Physiol Heart Circ Physiol 2006;290:H286-H294.

8 . Weber KT. The proinflammatory heart failure phenotype: a case of integrative physiology. Am J Med Sci 2005;330:219-226.

9. Chhokar VS, Sun Y, Bhattacharya SK, Ahokas RA, Myers LK, Xing Z, Smith RA, Gerling IC, Weber KT. Loss of bone minerals and strength in rats with aldosteronism. Am J Physiol Heart Circ Physiol 2004;287:H2023-H2026.

10. Zikos D, Langman C, Gafter U, Delahaye B, Lau K. Chronic DOCA treatment increases Ca absorption: role of hypercalciuria and vitamin D. Am J Physiol 1986; 251:E279-E284.

11. Fujita T, Palmieri GM. Calcium paradox disease: calcium deficiency prompting secondary hyperparathyroidism and cellular calcium overload. J Bone Miner Metab 2000; 18:109-125.

12. Sun Y, Zhang J, Lu L, Chen SS, Quinn MT, Weber KT. Aldosterone-induced inflammation in the rat heart : role of oxidative stress. Am J Pathol 2002;161:1773-1781.

13. Ahokas RA, Sun Y, Bhattacharya SK, Gerling IC, Weber KT. Aldosteronism and a proinflammatory vascular phenotype: role of $\mathrm{Mg} 2+, \mathrm{Ca} 2+$, and $\mathrm{H} 2 \mathrm{O} 2$ in peripheral blood mononuclear cells. Circulation 2005;111:51-57.

14. Ahokas RA, Warrington KJ, Gerling IC, Sun Y, Wodi LA, Herring PA, Lu L, Bhattacharya SK, Postlethwaite AE, Weber KT. Aldosteronism and peripheral blood mononuclear cell activation: a neuroendocrine-immune interface. Circ Res 2003;93:e124-e135.

15. Pu Q, Neves MF, Virdis A, Touyz RM, Schiffrin EL. Endothelin antagonism on aldosterone-induced oxidative stress and vascular remodeling. Hypertension 2003;42:49-55.

16. Virdis A, Neves MF, Amiri F, Viel E, Touyz RM, Schiffrin EL. Spironolactone improves angiotensin-induced vascular changes and oxidative stress. Hypertension 2002;40:504-510.

17. Iglarz M, Touyz RM, Viel EC, Amiri F, Schiffrin EL. Involvement of oxidative stress in the profibrotic action of aldosterone. Interaction with the renin-angiotensin system. Am J Hypertens 2004;17:597-603.

18. Anand IS, Ferrari R, Kalra GS, Wahi PL, Poole-Wilson PA, Harris PC. Edema of cardiac origin. Studies of body water and sodium, renal function, hemodynamic indexes, and plasma hormones in untreated congestive cardiac failure. Circulation 1989;80:299-305.

19. Villarreal D, Freeman RH, Johnson RA. Neurohumoral modulators and sodium balance in experimental heart failure. Am J Physiol 1993;264:H1187-H1193.

20. Weber KT. Aldosterone in congestive heart failure. N Engl J Med 2001;345:1689-1697.

21. Jessup M, Brozena S. Heart failure. N Engl J Med 2003;348:2007-2018.

22. Law PH, Sun Y, Bhattacharya SK, Chhokar VS, Weber KT. Diuretics and bone loss in rats with aldosteronism. J Am Coll Cardiol 2005;46:142-146.

23. Lee AH, Mull RL, Keenan GF, Callegari PE, Dalinka MK, Eisen HJ, Mancini DM, DiSesa VJ, Attie MF. Osteoporosis and bone morbidity in cardiac transplant recipients. Am J Med 1994;96:35-41.
24. Shane E, Mancini D, Aaronson K, Silverberg SJ, Seibel MJ, Addesso V, McMahon DJ. Bone mass, vitamin D deficiency, and hyperparathyroidism in congestive heart failure. Am J Med 1997;103:197-207.

25. Stein MS, Scherer SC, Walton SL, Gilbert RE, Ebeling PR, Flicker L, Wark JD. Risk factors for secondary hyperparathyroidism in a nursing home population. Clin Endocrinol (Oxf) 1996;44:375-383.

26. Seligmann H, Halkin H, Rauchfleisch S, Kaufmann N, Motro M, Vered Z, Ezra D. Thiamine deficiency in patients with congestive heart failure receiving long-term furosemide therapy: a pilot study. Am J Med 1991;91:151-155.

27. Zittermann A, Schleithoff SS, Tenderich G, Berthold HK, Korfer R, Stehle P. Low vitamin D status: a contributing factor in the pathogenesis of congestive heart failure? J Am Coll Cardiol 2003;41:105-112.

28. Holick MF. Sunlight and vitamin D for bone health and prevention of autoimmune diseases, cancers, and cardiovascular disease. Am J Clin Nutr 2004;80:1678S$1688 \mathrm{~S}$.

29. Laguardia SP, Dockery BK, Bhattacharya SK, Nelson MD, Carbone LD, Weber KT. Secondary hyperparathyroidism and hypovitaminosis D in African-Americans with decompensated heart failure. Am J Med Sci 2006; 332:112-118.

30. Arroyo M, Laguardia SP, Bhattacharya SK, Nelson MD, Johnson PL, Carbone LD, Newman KP, Weber KT. Micronutrients in African-Americans with decompensated and compensated heart failure. Transl Res 2006;148:301-308.

31. Schleithoff SS, Zittermann A, Tenderich G, Berthold HK, Stehle P, Koerfer R. Vitamin D supplementation improves cytokine profiles in patients with congestive heart failure: a double-blind, randomized, placebo-controlled trial. Am J Clin Nutr 2006;83:754-759.

32. Witte KK, Clark AL. Chronic heart failure and multiple micronutrient supplementation: realistic hope or idealistic conjecture? Heart Fail Monit 2005;4:123-129.

33. Mahon BD, Gordon SA, Cruz J, Cosman F, Cantorna MT. Cytokine profile in patients with multiple sclerosis following vitamin D supplementation. J Neuroimmunol 2003; 134:128-132.

34. Xia YM, Hill KE, Burk RF. Biochemical studies of a seleniumdeficient population in China: measurement of selenium, glutathione peroxidase and other oxidant defense indices in blood. J Nutr 1989;119:1318-1326.

35. van Rij AM, Thomson CD, McKenzie JM, Robinson MF. Selenium deficiency in total parenteral nutrition. Am J Clin Nutr 1979;32:2076-2085.

36. Reeves WC, Marcuard SP, Willis SE, Movahed A. Reversible cardiomyopathy due to selenium deficiency. JPEN J Parenter Enteral Nutr 1989;13:663-665.

37. Ripa S, Ripa R, Giustiniani S. Are failured cardiomyopathies a zinc-deficit related disease? A study on $\mathrm{Zn}$ and $\mathrm{Cu}$ in patients with chronic failured dilated and hypertrophic cardiomyopathies. Minerva Med 1998;89:397-403.

38. Zumkley H, Bertram HP, Vetter H, Zidek W, Losse H. Zinc metabolism during captopril treatment. Horm Metab Res $1985 ; 17: 256-258$.

39. Koren-Michowitz M, Dishy V, Zaidenstein R, Yona O, Berman $\mathrm{S}$, Weissgarten J, Golik A. The effect of losartan and losartan/hydrochlorothiazide fixed-combination on magnesium, zinc, and nitric oxide metabolism in hypertensive patients: a prospective open-label study. Am J Hypertens 2005;18:358-363.

40. Wester PO. Urinary zinc excretion during treatment with different diuretics. Acta Med Scand 1980;208:209-212. 
41. Abu-Hamdan DK, Desai H, Sondheimer J, Felicetta J, Mahajan $\mathrm{S}, \mathrm{McDonald} \mathrm{F}$. Taste acuity and zinc metabolism in captopril-treated hypertensive male patients. Am J Hypertens 1988;1:303S-308S.

42. Witte KK, Nikitin NP, Parker AC, von Haehling S, Volk HD, Anker SD, Clark AL, Cleland JG. The effect of micronutrient supplementation on quality-of-life and left ventricular function in elderly patients with chronic heart failure. Eur Heart J 2005;26:2238-2244.

\section{Author Affiliations}

Shadwan Alsafwah, MD

Division of Cardiovascular Diseases

Department of Medicine

University of Tennessee Health Science Center

Memphis, Tennessee

Stephen P. LaGuardia, MD

Division of Cardiovascular Diseases

Department of Medicine

University of Tennessee Health Science Center

Memphis, Tennessee

Maximiliano Arroyo, MD

Division of Cardiovascular Diseases

Department of Medicine

University of Tennessee Health Science Center

Memphis, Tennessee

Brian K. Dockery, MD

Division of Cardiovascular Diseases

Department of Medicine

University of Tennessee Health Science Center

Memphis, Tennessee

Syamal K. Bhattacharya, PhD

Division of Cardiovascular Diseases

Departments of Medicine and Surgery

University of Tennessee Health Science Center

Memphis, Tennessee

Robert A. Ahokas, PhD

Department of Obstetrics \& Gynecology

University of Tennessee Health Science Center

Memphis, Tennessee

Kevin P. Newman, MD

Division of Cardiovascular Diseases

Department of Medicine

University of Tennessee Health Science Center

Memphis, Tennessee 